\title{
A SYSTEMATIC REVIEW TO INVESTIGATE THE EVIDENCE OF THE VISUOSPATIAL WORKING MEMORY DYSFUNCTION IN THE AUTISM SPECTRUM DISORDER.
}

\section{Hadeer Sobhy Mohammed, Safaa Refaat El-Sady, Nirvana Gamal EL-Din Hafez, and Mona Sameeh Khodeir}

\author{
Phoniatrics Unit- \\ Otorhinolaryngology \\ Department, Faculty of \\ Medicine, Ain Shams University \\ Corresponding Author: \\ HadeerSobhy Mohammed \\ Mobile (+2) 01093544986 \\ E-mail: \\ hadeersob7y91@gmail.com \\ Received: $11 / 6 / 2020$ \\ Accepted: 5/7/2020
}

Online ISSN: 2735-3540

\begin{abstract}
:
Background: Impaired working memory and executive function is one of the major theories that explain the cognitive bases of ASD symptoms. However, the previous research findings on the visuospatial working memory (VSWM) were inconsistent and widely varied.
\end{abstract}

Aim of the Work: This work aims to examine the evidence for VSWM dysfunction in ASD children. This will be made by conducting a systematic review of literature in this topic area.

Material and Methods: Three electronic databases (Pubmed, Science Direct, and CINHAL) were searched for articles. Relevant studies were further evaluated and studies that met inclusion criteria were reviewed

Results: The literature search yielded 3048 studies. Forty-two articles were further evaluated to be included. Seven studies met all inclusion criteria and were chosen for review. The quality of the included studies assessed with the Newcastle Ottawa Quality Assessment Scale. The impairment of VSWM in ASD children was reported in 4 studies, while there are 3 studies with the opinion of intact VSWM. So, within this small number of included studies the results of VSWM in ASD were different.

Conclusion: This systematic review generally couldn't reach a conclusive evidence about VSWM dysfunction in children with ASD. This is mainly due to the small number of the included articles and the small sample size in almost all these studies. Besides, different measures used in the assessment of visuospatial working memory in those children as well as ignorance of receptive language profile of ASD children, intra-individual difference assessment of ASD group, ASD comorbidities especially ADHD and dyspraxia and type of treatment they received. More research works with neuroimaging support are required taking in consideration intra-individual aptitudes, receptive language profile, comorbidities and type of treatment of ASD group in order to provide further relevant assessment on neural bases of VSWM in ASD children.

Keywords: Working memory, Visuospatial working memory, ASD, CANTAB, Crosi block tapping test.

\section{INTRODUCTION:}

Autism spectrum disorder (ASD) is a range of neurodevelopmental disorders characterized by deficits in social communication and social interaction, with repetitive and restricted behaviors, interests, and activities $^{[1]}$. Symptoms of ASD have been related to several cognitive deficits, such as language impairments, problems with executive control, and a tendency to focus on details rather than global ${ }^{[2]}$. Three major theories result from these cognitive 
deficits in an attempt to explain symptoms of ASD which include:1) the hypothesis of deficits in theory of mind, 2) the central coherence theory, and 3) the executive dysfunction theory.

Regarding the hypothesis of impairment in theory of mind which is firstly anticipated by Baron-Cohen et al. ${ }^{[3]}$ and considered that autistic children are not able to infer the mental states of the others, while the central coherence theory that is firstly proposed by Frith $^{[4]}$ states that autistic children exhibit a qualitatively different style of information processing than normally developed children. The executive dysfunction theory is one of the most influential cognitive accounts for ASD. A wide range of executive function deficits have been found in $\mathrm{ASD}^{[5,6,7,8]}$, which may explain their social and non-social problems, such as repetitive behaviors and restricted interests in the daily life ${ }^{[5]}$ Executive function is a term that includes different abilities such as planning, self-regulation, inhibition, shifting, initiation and monitoring of actions, and working memory ${ }^{[9]}$. Working memory is the cognitive function of limited capacity responsible for storage information over a brief time, manipulating it, and using it in thinking. It is a critical contributor to such essential cognitive functions and properties as language comprehension, learning, planning, spatial relations, visualization, reasoning, and general fluid intelligence ${ }^{[10]}$. Working memory is more than just the ability to remember a series of numbers long enough to repeat them. It is the capacity to manipulate the information you are holding in your mind. So, it is the cognitive system that temporarily maintains information for further processing during perception and action ${ }^{[11]}$. According to Baddeley's model of working memory, working memory consists of three functional components which are the central executive, phonological loop and visuospatial sketchpad. This model is called a multicomponent model of working memory. The phonological loop and visuospatial sketchpad are independent socalled slave systems and both existing alongside the long-term memory ${ }^{[12]}$ which is extended by the addition of the episodic buffer as a fourth component in [13]. According to Logie ${ }^{[14]}$, the visuospatial sketchpad is the second slave system responsible for manipulating visual images and mental maps. It is divided into 1) visual subsystem responsible for processing and maintenance of visual information e.g. shape, color, and texture, and 2) Spatial subsystem responsible for processing and maintenance of locations of objects and persons in the space.

It has been hypothesized that impairment of working memory is associated with either deficits in communication and social interaction ${ }^{[15,16]}$ or repetitive and restricted behaviors ${ }^{[17,18]}$ in ASD children. So, it is important to understand more about the relation of working memory to ASD symptoms.

Regarding the visuospatial working memory, previous research has provided inconclusive evidence about whether people with ASD are impaired in visuospatial working memory. Several studies have found that individuals with ASD had visuospatial working memory deficits $[19,20$, ${ }^{21]}$. However, other studies have reported normal visuospatial working memory in $\mathrm{ASD}^{[22]}$. The findings from previous research on visuospatial WM impairments in ASD has been inconsistent. Therefore, it was decided to construct the present study as an attempt to resolve this conflict and reach a conclusive evidence of whether the visuospatial WM is impaired or not in children with ASD.

Method: The systematic review was carried out according to the guidelines of the PRISMA - DTA protocol for systematic reviews and meta-analysis ${ }^{[23]}$. 


\section{Eligibility Criteria - Study Selection}

Studies selected for the current systematic review were observational casecontrol studies in the English language that compare the visuospatial WM in children with ASD and the control group of typically developing children. Studies selected were published in the duration from 2005 to 2020 . The studies selected met the following selection criteria: participants in each study were children in the age range between 5 18 years old who were diagnosed with one of the ASD (Autism, Asperger's syndrome, PPD-NOS) and had an average intelligence quotient or above. We excluded studies with less than 5 participants and studies with ASD children who have any past or present history of any other psychiatric problems and peripheral hearing and/or visual sensory impairment. We included studies that diagnosed ASD according to DSM-IV criteria and supported their diagnosis by at least one of the following measures: Autism Diagnostic Interview-Revised "ADI-R" [24], Autism Diagnostic Observation Schedule "ADOS"[25], and Autism Diagnostic Observation Schedule-Generic "ADOS-G" [26].

We selected studies that assessed the visuospatial WM by one of the following tools: Spatial working memory task of Cambridge Neuropsychological Test Automated Battery (CANTAB) ${ }^{[27]}$, and/or Corsi block tapping test (Visuospatial working memory span task $)^{[28]}$.

\section{Literature Selection - Search Strategy:}

Two authors performed independent systematic titles and abstracts search based on the selection criteria. Studies were conducted up and located through electronic searches for studies in the English language in two databases: (1) Pubmed, (2) Science Direct, and (3) CINAHL between 2005 and 2020. A search strategy was developed by establishing a matrix of synonyms to cover all possible terms indicating autism spectrum disorder and the visuospatial WM.
The included terms were: Autism - Autism spectrum disorder - Asperger's syndrome PPD-NOS - visuospatial working memory spatial working memory - visual working memory

During the search, the search limitations of the PubMed and Science Direct were used including articles' language, age of participants, and publication date. Studies that were irrelevant in the early stages of the search on the bases of titles presented in the electronic searches were excluded. Studies that seemed eligible from their title or abstract were obtained in full-text and underwent further inspection based on the eligibility criteria. Monthly search updates were done to check for additional article inclusions, and this resulted in no additional article inclusion up to date. Any discrepancy between the two authors was solved through discussion meetings, and a third author was consulted if necessary.

\section{Data Extraction and Analysis:}

Two authors collected independently the following information from the recruited studies: the study's authors, publication year, country, study design, sample size, participants' ages, gender and IQ, tools used to diagnose the ASD, and the tools used to assess VSWM. Data related to the comparison of the VSWM between the ASD children and the control normal group in each study, were also extracted.

\section{Quality or Risk of Bias Assessment:}

Two review authors independently assessed the methodological quality using the Newcastle-Ottawa Quality Assessment Scale $(\mathrm{NOS})^{[29]}$, that included a description and a judgment (low risk of bias, high risk of bias, or unclear risk of bias) for the following domains for each of the included studies: 1) Selection (case definition representativeness of cases - the selection of controls - definition of controls), 2) Comparability of cases and controls based on the design or analysis as regard matching with study controls for IQ, age and language 
assessment, and 3) Exposure (ascertainment of exposure - same method of ascertainment for cases and controls). Non-response rate cannot be applied in our included studies? Studies were given a maximum of 1 point for each of the six items and 2 points for comparability only, making the maximum score 8 points. According to total score studies were categorized into studies with a very high risk of bias (0-3), high risk of bias (4-6), and low risk of bias (7-9) ${ }^{[30]}$.

\section{RESULTS:}

Results of Literature Search:

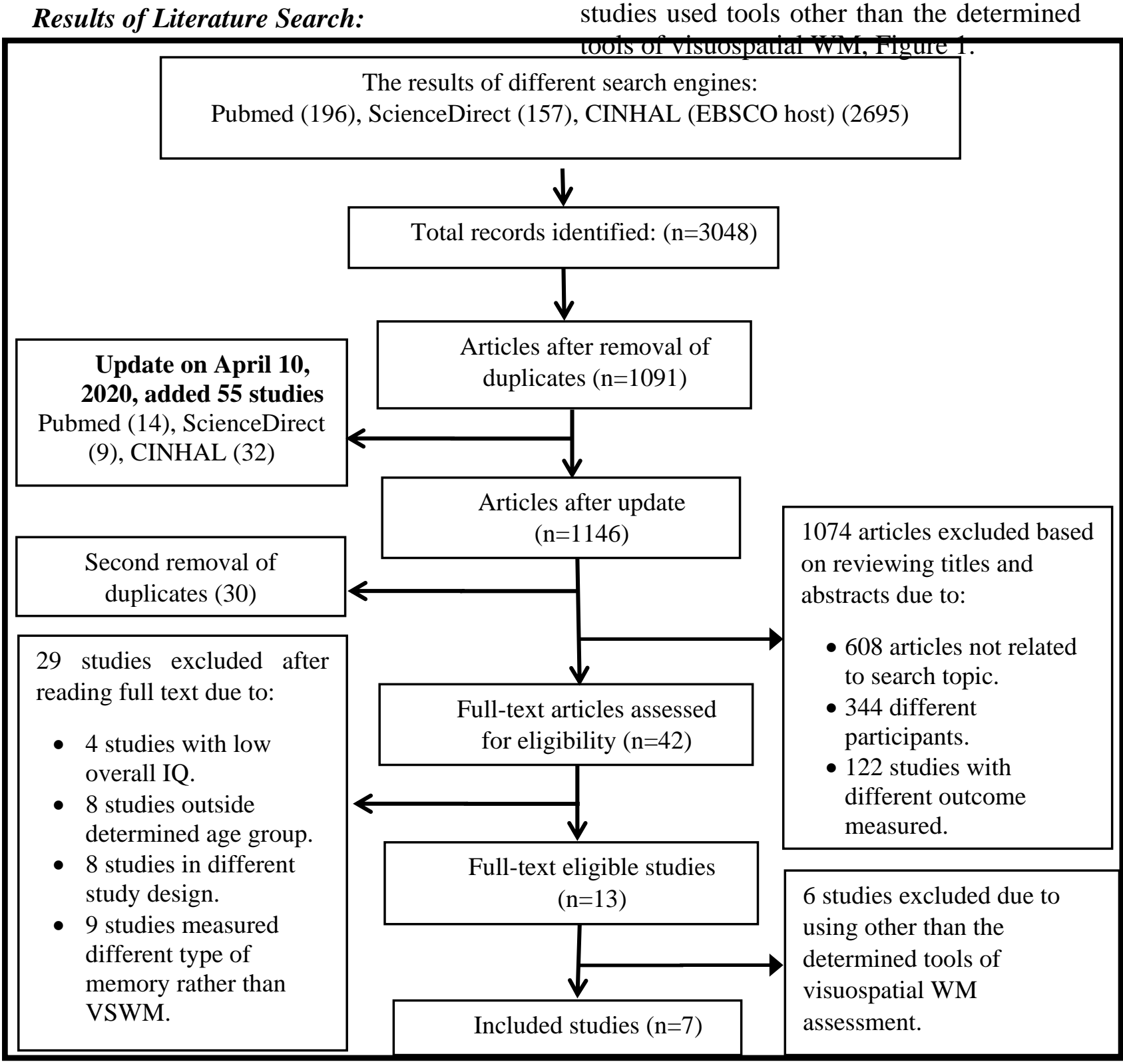

Figure1: The flow chart of included and excluded studies.
Initially, the search strategy yielded 3047 studies. After the removal of duplicates, 1091 studies remained for further screening. Based on titles and abstracts screening, 1074 more were removed and the result was 42 potentially eligible studies. After full-text reading, another 35 studies were excluded. Reasons for exclusion were different study designs (8 studies), studies included ASD children outside the selected age range (8 studies), studies with ASD children with below-average IQ (4 studies), studies measured different type of memory rather than the VSWM (9 studies) and 6 studies used tools other than the determined couis of visuospatial wivi, Figure 1.

The results of different search engines:

Pubmed (196), ScienceDirect (157), CINHAL (EBSCO host) (2695) 


\section{Study Characteristics:}

\section{Study design:}

Seven studies fulfilled all the inclusion

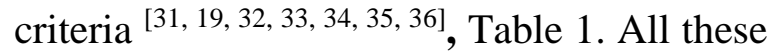
studies were observational comparative case-control studies.

\section{Participants Characteristics:}

The 7 included studies involved 320 participants. The sample size ranged from 20 to 58 participants. The ages of study participants ranged from 5 to 18 years old. The average mean of full-scale IQ and standard of deviation ranging from the smallest mean $( \pm \mathrm{SD})$ in the study by Wang et al. ${ }^{[36]}$ which was $93.25 \pm 7.23$ to the highest mentioned in Landa and Goldberg ${ }^{[19]}$ which was $113.4 \pm 14.34$. One study ${ }^{[34]}$ did not mention the mean full-scale IQ but the authors mentioned that the participants did not present associated mental retardation, according to Raven's Colored Progressive Matrices test - Special Scale ${ }^{[37,38]}$. Most studies mentioned the gender of the study participants (with both males and females) except for one study ${ }^{[19]}$, Table (1).

Table 1. Summary of the characteristics of the included studies.

\begin{tabular}{|c|c|c|c|c|c|}
\hline Type of ASD & $\begin{array}{c}\text { Mean full-scale } \\
\text { IQ } \pm \text { SD }\end{array}$ & $\begin{array}{c}\text { Gender } \\
\text { Male: Female }\end{array}$ & $\begin{array}{c}\text { Mean age } \\
\text { in years } \pm \text { SD }\end{array}$ & Sample size & $\begin{array}{c}\text { Study authors } \\
\text { (publication year) }\end{array}$ \\
\hline HFA & $\begin{array}{c}\text { Autism: } 96.5 \pm 15.9 \\
\text { ADHD: } 113.8 \pm 10.3 \\
\text { TD: } 112.6 \pm 12.1\end{array}$ & $\begin{array}{c}\text { Autism: } 13: 4 \\
\text { ADHD: } 19: 2 \\
\text { TD: } 21: 11\end{array}$ & $\begin{array}{c}\text { Autism: } 10.3 \pm 1.8 \\
\text { ADHD: } 9.8 \pm 1.3 \\
\text { TD: } 10.4 \pm 1.5\end{array}$ & $\begin{array}{l}\text { Autism: } 17 \\
\text { ADHD: } 21 \\
\text { TD:32 }\end{array}$ & $\begin{array}{l}\text { Goldberg et al. } \\
\text { (2005) }\end{array}$ \\
\hline HFA & $\begin{array}{c}\text { Autism: } 109.7 \pm 15.80 \\
\text { TD: } 113.4 \pm 14.34\end{array}$ & - & $\begin{array}{c}\text { Autism: } 11.01 \pm 2.89 \\
\text { TD: } 11.00 \pm 2.85\end{array}$ & $\begin{array}{l}\text { Autism: } 19 \\
\text { TD: } 19\end{array}$ & $\begin{array}{c}\text { Landa andGoldberg } \\
(2005)\end{array}$ \\
\hline $\begin{array}{c}\text { HFA } \\
\text { Asperger's } \\
\text { syndrome }\end{array}$ & - & $\begin{array}{l}\text { ASD: } 11: 13 \\
\text { TD: } 28: 6\end{array}$ & $\begin{array}{l}\text { ASD: } 11.46 \pm 2.32 \\
\text { TD: } 12.04 \pm 2.52\end{array}$ & $\begin{array}{l}\text { ASD: } 24 \\
\text { TD: } 21\end{array}$ & $\begin{array}{c}\text { Edgin and } \\
\text { Pennington } \\
(2005)\end{array}$ \\
\hline AS & $\begin{array}{c}\text { AS: } 102.3 \pm 15.9 \\
\text { TD: } 1 \cdot 9.5 \pm 6.4\end{array}$ & $\begin{array}{l}\text { AS: } 8: 2 \\
\text { TD: } 8: 2 \\
\end{array}$ & $\begin{array}{l}\text { AS: } 14.7 \pm 5.0 \\
\text { TD: } 13.8 \pm 5.3 \\
\end{array}$ & $\begin{array}{l}\text { AS: } 10 \\
\text { TD: } 10 \\
\end{array}$ & $\begin{array}{l}\text { Kaufmann } \\
\text { et al. (2013) }\end{array}$ \\
\hline $\begin{array}{c}\text { Autism } \\
\text { Asperger's } \\
\text { syndrome }\end{array}$ & - & $\begin{array}{l}\text { ASD: } 9: 2 \\
\text { TD: } 17: 2\end{array}$ & $\begin{array}{l}\text { ASD: } 11.73 \pm 1.90 \\
\text { TD: } 11.42 \pm 1.80\end{array}$ & $\begin{array}{l}\text { ASD:11 } \\
\text { TD:19 }\end{array}$ & $\begin{array}{l}\text { Czermainski } \\
\text { et al. (2014) }\end{array}$ \\
\hline $\begin{array}{c}\text { Autism } \\
\text { AS } \\
\text { PDD-NOS } \\
\end{array}$ & & $\begin{array}{l}\text { ASD: } 14: 6 \\
\text { TD: } 17: 3\end{array}$ & $\begin{array}{c}\text { ASD: } 8.55 \pm 2.30 \\
\text { TD: } 9.10 \pm 2.24\end{array}$ & $\begin{array}{l}\text { ASD: } 20 \\
\text { TD: } 20\end{array}$ & $\begin{array}{c}\text { Macizo } \\
\text { et al. } \\
(2016)\end{array}$ \\
\hline ASD & $\begin{array}{c}\text { ASD: } 99.5 \pm 17.78 \\
\text { ADHD: } 93.25 \pm 7.23 \\
\text { TD: } 110.14 \pm 11.91\end{array}$ & $\begin{array}{c}\text { ASD: } 20: 1 \\
\text { ADHD: } 23: 5 \\
\text { TD: } 19: 9\end{array}$ & $\begin{array}{l}\text { ASD: } 9.05 \pm 2.38 \\
\text { TD: } 8.92 \pm 1.68\end{array}$ & $\begin{array}{l}\text { ASD: } 21 \\
\text { ADHD: } 28 \\
\text { TD: } 28\end{array}$ & $\begin{array}{l}\text { Wang } \\
\text { et al. } \\
(2018)\end{array}$ \\
\hline
\end{tabular}

Characteristics of the Tools used to Diagnose ASD:

The included studies selected to diagnose ASD on validated and verified tools. Two studies ${ }^{[19,}$ 31] relied on their diagnosis of ASD on ADI-R and ADOS only. Three studies ${ }^{[34-36]}$ depended on DSMIV criteria in the diagnosis of ASD. One study $^{[32]}$ diagnosed ASD cases by ADI-R only. All the included studies did not determine the age at which the child received any treatment. Only 2 studies mentioned that some ASD participants had received medical treatment. Goldberg et al. ${ }^{[31)}$ mentioned that the ASD participants had received selective serotonin reuptake inhibitors and psychostimulant [only in two participants), these stimulant medications were withheld for 48 hours before testing. Wang et al. ${ }^{[36]}$ revealed that all the participants were asked not to take any central nervous system "CNS" active medications for at least 24 hours before all tests ensuring sufficient period for fully washing out, Table 2. 
Table 2. Summary of the characteristics of the tools used to diagnose ASD.

\begin{tabular}{|c|c|c|c|c|}
\hline $\begin{array}{l}\text { Type of treatment and time of withdrawal before } \\
\text { testing }\end{array}$ & $\begin{array}{l}\text { Age at } \\
\text { which the child } \\
\text { received } \\
\text { treatment }\end{array}$ & $\begin{array}{l}\text { Tools used } \\
\text { to diagnose } \\
\text { ASD }\end{array}$ & $\begin{array}{l}\text { Age at } \\
\text { which } \\
\text { ASD was } \\
\text { diagnosed }\end{array}$ & $\begin{array}{c}\text { Study } \\
\text { author } \\
\text { (publication } \\
\text { year) }\end{array}$ \\
\hline 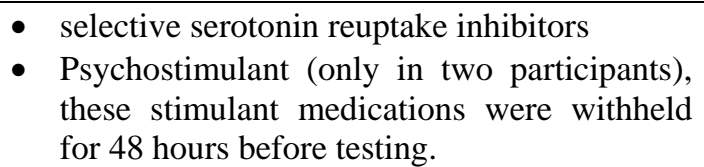 & $\begin{array}{l}\text { Not } \\
\text { mentioned }\end{array}$ & $\begin{array}{l}(\mathrm{ADI}-\mathrm{R}) \\
(\mathrm{ADOS}) \\
(\mathrm{ADOS}-\mathrm{G})\end{array}$ & $8-12 y$ & $\begin{array}{l}\text { Goldberg } \\
\text { et al. } \\
(2005)\end{array}$ \\
\hline Not mentioned & $\begin{array}{c}\text { Not } \\
\text { mentioned }\end{array}$ & $\begin{array}{l}(\mathrm{ADI}-\mathrm{R}) \\
(\mathrm{ADOS}) \\
(\mathrm{ADOS}-\mathrm{G})\end{array}$ & $7-17.5 \mathrm{y}$ & $\begin{array}{l}\text { Landa and } \\
\text { Goldberg } \\
(2005)\end{array}$ \\
\hline Not mentioned & $\begin{array}{c}\text { Not } \\
\text { mentioned }\end{array}$ & $\begin{array}{l}\text { Clinical } \\
\text { diagnosis, } \\
\text { (ADI-R) }\end{array}$ & $\begin{array}{c}\text { Not } \\
\text { mentioned }\end{array}$ & $\begin{array}{l}\text { Edgin and } \\
\text { Pennington } \\
(2005)\end{array}$ \\
\hline Not mentioned & $\begin{array}{l}\text { Not } \\
\text { mentioned }\end{array}$ & $\begin{array}{l}\text { DSM-IV- } \\
\text { TR, } \\
\text { ADI-R, } \\
\text { ADOS }\end{array}$ & $7-18 y$ & $\begin{array}{l}\text { Kaufmann } \\
\text { et al. } \\
\text { (2013) }\end{array}$ \\
\hline Not mentioned & $\begin{array}{c}\text { Not } \\
\text { mentioned }\end{array}$ & DSM-IV & $9-15 y$ & $\begin{array}{l}\text { Czermainski } \\
\text { et al. } \\
(2014) \\
\end{array}$ \\
\hline Not mentioned & $\begin{array}{c}\text { Not } \\
\text { mentioned }\end{array}$ & $\begin{array}{l}\text { DSM-IV, } \\
\text { Parents } \\
\text { completed } \\
\text { the (SCQ) }\end{array}$ & $5-13 y$ & $\begin{array}{l}\text { Macizo et } \\
\text { al. } \\
(2016)\end{array}$ \\
\hline $\begin{array}{l}\text { - All the participants were asked not to take } \\
\text { any CNS active medications for at least } 24 \\
\text { hours before all tests ensuring sufficient } \\
\text { period for fully washing out. }\end{array}$ & $\begin{array}{c}\text { Not } \\
\text { mentioned }\end{array}$ & DSM-IV & $6-15 y$ & $\begin{array}{l}\text { Wang et al. } \\
\quad(2018)\end{array}$ \\
\hline
\end{tabular}

Characteristics of tools used for the assessment of VSWM:

Four studies $[19,31-33]$ used the spatial working memory task of CANTAB in assessment of the VSWM. The aim of this test is that, by touching the boxes, the participant should find one blue "token" in one of the presented boxes and use them to fill up an empty column on the right side of the screen. Once a blue token has been found within a particular box, that box should never be used again to hide a token. Returning to an empty box where a target was already being found is referred to as a "between-search error." A "within-search error" refers to responses to a box previously opened and shown to be empty earlier in the same search sequence. A "double error" is an error that can be categorized as both a between-search error and within-search error. A "strategy score" is estimated from the number of searches that start from the same location.

Three studies [34-36] used the Crosi Block Tapping Test (visuospatial working memory span task) that applied to measure the visuospatial span which is standardized and validated by Corsi ${ }^{[28]}$. In which nine boxes are displayed on the screen in random distribution and the boxes remain for $500 \mathrm{~ms}$ after the sequence completed and the participants should recall the sequence in which the boxes appeared. The participants should complete three trials in each sequence level of two, three, four, five, six, seven, eight, nine boxes. The visuospatial span of the participant measured by the largest sequence in which two of three trials are correctly recalled. Table 3 . 
Table 3. Summary of the tools used to assess VSWM and the results of the individual studies.

\begin{tabular}{|c|c|c|}
\hline Main results of the study & $\begin{array}{c}\text { The tools } \\
\text { used to } \\
\text { assess } \\
\text { VSWM } \\
\end{array}$ & \begin{tabular}{|c|c}
$\begin{array}{c}\text { Study } \\
\text { author } \\
\text { (publication } \\
\text { year) }\end{array}$ \\
\end{tabular} \\
\hline $\begin{array}{l}\text { - HFA made significantly more total between search errors compared to } \\
\text { controls. }(\mathrm{p}<.05) \\
\text { - HFA made significantly more between-search errors compared to controls } \\
\text { on 6-boxes (mid-difficulty) and } 8 \text {-boxes (most difficult). } \\
\text { - There was no significant group difference in within-errors and double- } \\
\text { errors ( }>\text {-18). } \\
\text { - There was no significant group difference in strategy score }(\mathrm{p}>.48) \text {. } \\
\text { - Children with ADHD made significantly more between search errors than } \\
\text { controls on (8-boxes) only. } \\
\text { - Conclusion: The spatial working memory is impaired in both HFA and } \\
\text { ADHD but more severely in HFA. }\end{array}$ & $\begin{array}{c}\text { Spatial } \\
\text { working } \\
\text { memory } \\
\text { task of } \\
\text { (CANTAB) }\end{array}$ & $\begin{array}{l}\text { Goldberg } \\
\text { et al. } \\
\text { (2005) }\end{array}$ \\
\hline $\begin{array}{l}\text { - Compared to controls, participants with HFA more frequently made } \\
\text { between-search errors }(\mathrm{p}<.01) \text {. } \\
\text { - There was an interaction between performance and task difficulty. While } \\
\text { participants with HFA and controls performed similarly on searches with } \\
\text { three and four items, participants with HFA showed significantly more } \\
\text { between-search errors often on 6-boxes trials and showed a trend toward } \\
\text { making more of such errors on the 8-boxes trials compared to controls. } \\
\text { - On 8-boxes trials only, participants with HFA made more within-search } \\
\text { errors and more double-errors. } \\
\text { - Participants with HFA used poorer search strategies compared to controls. } \\
\text { - Conclusion: the participants with ASD showed spatial working memory } \\
\text { deficits mainly on the tasks with higher working memory load. }\end{array}$ & $\begin{array}{c}\text { Spatial } \\
\text { working } \\
\text { memory } \\
\text { task of } \\
\text { (CANTAB) }\end{array}$ & $\begin{array}{c}\text { Landa } \\
\text { and } \\
\text { Goldberg } \\
(2005)\end{array}$ \\
\hline $\begin{array}{l}\text { - No differences were found between the groups on the between errors or } \\
\text { strategy score ( }>.55 \text { for both). } \\
\text { - Both variables were significantly related to chronological age ( } p<.001 \text { for } \\
\text { both) and Block Design standard score ( }<.001 \text { for both). } \\
\text { - There was no evidence for differential change with age between the groups } \\
\text { or any differences related to gender. } \\
\text { - Conclusion: children with ASD show intact spatial working memory. } \\
\text { There is no difference between Asperger's syndrome and autism on spatial } \\
\text { tasks. }\end{array}$ & $\begin{array}{l}\text { Spatial } \\
\text { working } \\
\text { memory } \\
\text { task of } \\
\text { (CANTAB) }\end{array}$ & \begin{tabular}{|c} 
Edgin \\
and \\
Pennington \\
$(2005)$
\end{tabular} \\
\hline $\begin{array}{l}\text { - Compared with controls, children with Asperger's syndrome performed } \\
\text { quicker but at the same time they committed numerically, but not } \\
\text { statistically, more errors regarding the spatial working memory task (group } \\
\text { differences being most pronounced on mid difficult 6-box trials (p=.229) } \\
\text { and the most difficult } 8 \text {-box trials }(\mathrm{p}=.371) \text { ). } \\
\text { - By association between brain function and brain structure, quicker spatial } \\
\text { working memory response latency (RT) in children with AS was } \\
\text { significantly correlated to fronto-parietal brain regions and specific fronto- } \\
\text { executive functions which characterized by increased frontal white matter } \\
\text { and decreased parietal grey matter. } \\
\text { - Conclusion: both groups performed about equally well with interaction } \\
\text { with task difficulty. }\end{array}$ & $\begin{array}{l}\text { Spatial } \\
\text { working } \\
\text { memory } \\
\text { task of } \\
\text { (CANTAB), } \\
\text { Structural } \\
\text { Brain } \\
\text { imaging } \\
\text { using MRI. }\end{array}$ & $\begin{array}{l}\text { Kaufmann } \\
\text { et al. } \\
\text { (2013) }\end{array}$ \\
\hline $\begin{array}{l}\text { - In the Visuospatial Working Memory task, the clinical group presented } \\
\text { performance significantly below that of the control group, in terms of total } \\
\text { score and visuospatial span scores (more visuospatial sequences repeated } \\
\text { correctly), suggesting the presence of impairments in the visuospatial } \\
\text { component and central executive of the working memory. In the clinical } \\
\text { group, } 20 \% \text { of the participants achieved the maximum sequence of correct }\end{array}$ & $\begin{array}{c}\text { Visuospatial } \\
\text { working } \\
\text { memory } \\
\text { span test }\end{array}$ & $\begin{array}{l}\text { Czermainski } \\
\text { et al. } \\
\text { (2014) }\end{array}$ \\
\hline
\end{tabular}


responses in the task (span $=5), 40 \%$ correctly presented sequences of four items ( $\operatorname{span}=4), 20 \%$ of three items ( $\operatorname{span}=3$ ) and $20 \%$ of two items $($ span $=2)$. In the control group, $78 \%$ of the participants achieved the maximum span for the task ( $\operatorname{span}=5), 15 \%$ correctly presented sequences of four items ( $\operatorname{span}=4)$ and $5 \%$ of three items ( $\operatorname{span}=3)$.

- There were no differences between ASD children and control children regarding the visuospatial span nor in the overall number of recalled trials in the visuospatial task $(\mathrm{p}=0.16)$.

- There was a significant correlation between visuospatial span and IQ; a visuospatial span was higher in HFA than LFA.

- Conclusion: No visuospatial WM deficits were found when IQ was controlled, and simple tasks are used.

- There was significantly poorer VSWM performance in the ASD group than TD and ADHD groups.

- Pearson correlation coefficient between executive function and VSWM showed that in ASD group the CA showed +ve relationship with VSWM scores while PE and TE showed

-ve relationship with VSWM scores.

- Conclusion: the ASD group showed visuospatial WM deficits and there was association between visuospatial WM performance and executive function especially problem-solving ability.

\section{Results of Individual Studies:}

Studies by Goldberg et al. ${ }^{[31]}$ and Landa and Goldberg ${ }^{[19]}$ who measured VSWM by the spatial working memory task of (CANTAB) found that children of HFA performed worse than controls in remembering locations where tokens were previously found especially on mid-difficult and most difficult search problems. So, they suggested an impairment of VSWM depending on more errors recorded with ASD children comparing to TD children. They hinted also that there was interaction between the performance of ASD children and task difficulty. Also, they mentioned that the possible factor in their performance on the SWM task on not planning but to perseveration.

Both Wang et al. ${ }^{[36]}$ and Czermainski et al. ${ }^{[34]}$ compared the VSWM in ASD children with TD children, as well as executive function involvement to expect the VSWM performance in ASD. By using the Crosi block tapping test (VSWM span task) they reported that ASD children were worse in visuospatial storage span and showed poorer performance.
Edgin and Pennington ${ }^{[32]}$ found no differences between the groups on the between errors or strategy score using the spatial working memory task of [CANTAB] and reported also there is not a difference in spatial WM between autism and Asperger's syndrome. There is a significant relationship between spatial WM and chronological age and performance IQ.

Kaufmann et al. ${ }^{[33]}$ found that Asperger's syndrome children performed about equally well as typically developing children with interaction with task difficulty. They performed quicker but at the same time, they committed numerically but not statistically more errors that were obvious with mid-difficult and most difficult trials.

Lastly, Macizo et al. ${ }^{[35]}$ applied the CBTT and concluded that there were no visuospatial WM deficits in ASD children when IQ controlled, and simple task was used. Table 3.

\section{Summary of the main results:}

Among the recruited 7 studies, 4 studies found differences between ASD group and TD group in the tasks used for VSWM assessment and concluded that ASD group 
showed deficits in visuospatial working memory in comparison with typically developing group. While the remaining 3 studies found no differences between the ASD group and typically developing group and concluded intact VSWM in the ASD group.

\section{Risk of Bias and Applicability:}

We conducted the risk of bias assessment by Newcastle Ottawa Quality Assessment Scale ${ }^{[29]}$, Table 4. Upon that, the 7 included studies define cases adequately. Representativeness of the cases is consecutive representative series of cases except in Edgin Pennington [32] who recruited several ASD cases that had participated in previous studies and Macizo et al. ${ }^{[35]}$ who recruited ASD cases from normal schools.

Most of the included studies depended on community controls in selection except two studies ${ }^{[32,33]}$. In Edgin and Pinnington ${ }^{[32]}$ number of controls is less than the number of cases.

All included studies define controls with no history of any psychiatric or developmental disorders. All included studies applied proper matching between cases and controls regarding IQ and age except one study ${ }^{[35]}$ that did not mention the IQ matching. Regarding language assessment, only two studies applied proper matching Landa and Goldberg, ${ }^{[19]}$, Edgin and Pinnington ${ }^{[32]}$.

All included studies ascertain the exposure with interview not blinded to case/control status as blinding is impossible because exposure can be discovered only by interviewing the study participants, who obviously know whether they are a case. Three studies ${ }^{[31,34,35]}$ mentioned that they applied the same method of ascertainment for cases and controls while the remaining 4 included studies did not mention this item.

\section{DISCUSSION:}

Individuals with autism spectrum disorder (ASD) are often supported in daily life by visual presentations such as picture cards or illustrations. Therefore, they are considered to have visual strength. However, whether children with ASD are superior in visuospatial working memory remains inconsistent. Current research systematically reviewed existing literature that investigated the visuospatial working memory in individuals with autism spectrum disorder (ASD) including autism, Asperger's syndrome and PDD-NOS in attempt to resolve the conflict regarding the profile of visuospatial working memory in ASD to identify characteristics and challenges that would provide implications for academic assessment and intervention.

In this systematic review, we included 7 articles on children of either gender aged from 5 to 18 years old who were diagnosed with one of the ASD (Autism, Asperger's syndrome, PPD-NOS). We included studies that diagnosed ASD according to DSM-IV criteria and/or supported their diagnosis by at least one of the following measures: (ADI-R, ADOS, ADOS-G).We concluded that among the different methods used for assessment of visuospatial working memory, the spatial working memory task of CANTAB which has demonstrated sensitivity to detecting changes in neuropsychological performance of spatial working memory and it isn't a culturallybased or experience-dependent task, and the Crosi block tapping task that considered as visuospatial working memory span measuring tool. Both these tasks examine the visuospatial working memory by systematically varying the difficulty level (working memory load) which increases the amount of information that needs to be remembered and the number of trials that need to be maintained. Among the included studies there are 4 studies used spatial 
working memory task of CANTAB and the remaining 3 studies used the Crosi block tapping task (VSWM span task) as neuropsychological tests for assessment of this domain of working memory. In general, as we have reviewed before, there are 4 studies supported the opinion of impaired visuospatial WM in ASD children, 3 studies with the opinion of intact visuospatial WM. Thus, there is an impairment of visuospatial WM in children of ASD depending on the results of the 4 studies supported this opinion and this coincides with previous literature that supports that ASD had deficits

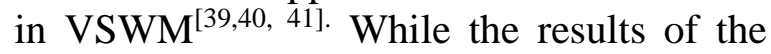
remaining 3 studies supporting the opinion of intact VSWM and this coincides with the Ozonoff and Strayer's ${ }^{[22]}$ findings who used three visuospatial WM tasks (a running memory task, a box search task and a spatial memory-span task with a progressively increasing memory load that required participants to remember the location of (1, 3 , or 5) colored geometric shapes over varying delay periods ( 1 or 5 seconds). They reported no statistical differences between a high functioning autism group and a control group.

There is evidence that the VSWM load plays a crucial role in the observation of VSWM deficits in ASD as reported in 3 studies $^{[31,19,33]}$. Tasks that place low WM demands are no sensitive to differences between children with ASD and control participants. However, when the tasks impose heavier demands, between-groups, differences become apparent. This finding consistent with previous studies of WM by showing that as task demands increase, the performance of individuals with autism becomes impaired relative to that of typically developing individuals ${ }^{[42]}$. Also, Steele et al. ${ }^{[20]}$ observed a significant interaction between group and VSWM load: the VSWM load had a greater impact on the performance of autistic than control individuals. Based on this finding, they suggested that deficits in this domain emerge only when the task imposes heavier demands of WM and the failure of some studies to detect spatial WM deficits might be due to the use of modest VSWM loads. Several obstacles came against making a fair comparison between the included studies. The first is the small number of included studies. Besides, all the included studies show a small sample size which decreases the statistical power of their results. Also, it was found that most of included studies ignored that ASD comprises a group of heterogeneous disorders with grading of severity and varying aptitudes. It was better to categorize them accordingly. Only one study reported that there wasn't group difference between autism and Asperger's syndrome $^{[32]}$. Clinically, it was mandatory to put receptive language profile in consideration before assessment of VSWM to be able to exclude comprehension deficit of command and task instructions which is reported in only two studies ${ }^{[19,}{ }^{32]}$. In addition, it was found that all included studies disregarded the clinical judgment of ASD comorbidities as if any of them was present especially ADHD or dyspraxia, it could share in reduced performance and poor results of the task. Reduced performance on the task may not arise from impairment of VSWM per se. It could result from deficits in attention and planning if associated with ADHD or impairments of motor coordination if associated with motor praxis dysfunction. As the success in the task depends not only the remembering ability but also on the ability to plan a sequence of movements and revise that plan dynamically. Also, we found that the included articles applied different assessment measures making it hard to evaluate and/or to compare the included studies. Come to the next, all the included studies did not mention the age at which the clinical group started to receive treatment and most of them didn't mention which type of treatment they received. If they received medical treatment, it would be stopped in 
adequate period before assessment of VSWM task according to type of drug used as some drugs have long half-life such as arpiprazole (3-4 days $)^{[43]}$ and fluoxetine (1-3 days $)^{[44]}$. Only 2 studies reported that some ASD participants had received medical treatment. Goldberg et al. ${ }^{[31]}$ mentioned that the ASD participants had received selective serotonin reuptake inhibitors and psycho stimulant (only in two participants), these stimulant medications were withheld for 48 hours before testing and the other study was Wang et al. ${ }^{[36]}$ which revealed that all the participants were asked not to take any central nervous system active medications for at least 24 hours before all tests ensuring period for fully washing out which isn't sufficient. Also, the performance of ASD group is expected to be affected according to which program of behavioral therapy they had received. Treatment and Education of Autistic and Related Communication Handicapped Children $\left(\right.$ TEACCH ${ }^{[45]}$ which aims to adapt the learning environment to the child's needs including visual structure of the activities and using visual instructions and organization in order to complete the task. So, higher performance of VSWM task is expected. On the other hand, Applied Behavioral Analysis $(A B A)^{[46]}$ is designed to enhance socially appropriate behavior and inhibit the challenging behaviors. Son-Rise program $^{[47]}$ is a loose program aims to participating in the child's repetitive behavior and following his interests in order to give a comfortable child not easy to participate in a test. So, lower performance of VSWM tasks is expected with second and third programs.

\section{Conclusion:}

This systematic review generally couldn't reach a conclusive evidence about VSWM dysfunction in children with ASD due to the small number of included studies which show a small sample size in almost all of them, different assessment measures as well as ignorance of receptive language profile of ASD children, intra-individual assessment of ASD group and ASD comorbidities especially ADHD and dyspraxia. In addition, all the included studies did not mention the age at which the clinical group start to receive treatment and which type of treatment they received and if they received medical treatment, it would have been stopped in appropriate period before assessment.

Direct research for intra-individual assessment of ASD aptitudes including VSWM to ascertain the strong points to build on and delineate the program of learning, lifestyle and even sport type. More neuroimaging supported studies are required to provide valuable observations into the neural basis of the VSWM impairment in ASD children. More research works are needed to explore the underlying mechanism of the impairment of the VSWM. Is the impairment of VSWM attributed to planning and executive function deficits or preservation symptoms in ASD children? More research works with a larger sample size are needed for further relevant assessment of the VSWM in ASD children and to examine VSWM across a wider range of ASD severity.

\section{REFERENCES:}

1. American Psychiatric Association "APA" (2013): Diagnostic and statistical manual of mental disorders $5^{\text {th }}$ edition (DSM-V). American Psychiatric Association, Washington, DC.

2. Kenworthy, L., Black, D.O., Harrison, B., della Rosa, A., \& Wallace, G.L. (2011): Are executive control functions related to autism symptoms in high-functioning children? Child Neuropsychology. 15, 425$440 . \quad$ https://doi.org/10.1080/ 09297040802646983.

3. Baron-Cohen, S., Leslie, A.M., \& Frith, U. (1985): Does the autistic child have a "theory of mind'? Cognition, 21, 37- 
46.https://doi.org/10.1016/0010-0277 (85)90022-8.

4. Frith, U. (2003): Autism: Explaining the enigma. Blackwell Publishing.

5. Hill, E.L. (2004a): Evaluating the theory of executive dysfunction in autism. Developmental Review, 24(2), 189-233.https://doi. org/10.1016/j.dr.2004.01.001.

6. Hill, E.L. (2004b): Executive dysfunction in autism. Trends in Cognitive Sciences, 8(1), 26-

32.https://doi.org/10.1016/j.tics.2003.11.00 3.

7. Pennington, B.F., \&Ozonoff, S. (1996): Executive functions and developmental psychopathology. Journal of Child Psychology and Psychiatry, 37, 51-87. https://doi.org/10.1111/j.1469-

7610.1996.tb01380.

8. Sanders, J., Johnson, K.A., Garavan, H., Gill, M., \& Gallagher, L. (2008): A review of neuropsychological and neuroimaging research in autistic spectrum disorders: Attention, inhibition, and cognitive flexibility. Research in Autism Spectrum Disorders, 2(1), 1-16.https://doi.org/10. 1016/j.rasd.2007.03.005.

9. Stuss, D.T., \& Knight, R.T. (Eds.). (2013): Principles of frontal lobe function. Oxford University Press.

10. Postle, B.R. (2006): Working memory as an emergent property of the mind and brain. Neuroscience, 139: 23-38.https://doi.org/10. 1016/j.neuroscience.2005.06.005.

11. Allen, R.J., Baddeley, A.D., \& Hitch, G.J. (2006): Is the binding of visual features in working memory resource-demanding? Journal of Experimental Psychology: General, 135(2), 298.https://psycnet.apa. org/doi/10.1037/0096-3445.135.2.298.

12. Baddeley, A.D., \& Hitch, G.J. (1974): Working Memory. In Bower, G. H. (Ed), the psychology of learning and motivation, 8:47-89.https://doi.org/10.1016/S00797421 (08)60452-1.

13. Baddeley, A.D. (2000): The episodic buffer: A new component of working memory? Trends in Cognitive Sciences, 4(11), 417-
423.https://doi.org/10.1016/S1364-6613(00) 01538-2.

14. Logie, R.H. (1995): Visuo-spatial working memory. Hove, UK: Lawrence Erlbaum Associates Ltd.

15. Gilotty, L., Kenworthy, L., Sirian, L., Black, D.O., \& Wagner, A.E. (2002): Adaptive skills and executive function in autism spectrum disorders. Child Neuropsychology; 8(4): 241-248. https://doi.org/ 10.1076/chin. 8.4.241.13504.

16. Oliveras-Rentas, R.E., Kenworhty, L., Roberson, R.B., Martin, A., \& Wallace, G.L. (2012): WISC-IV profile in high functioning autism spectrum disorders: Impaired speed is associated with increased autism communication symptoms and decreased adaptive communication abilities. Journal of Autism and Developmental Disorders, 42(5), 655-664. https://doi.org /10.1007/s10803-011-1289-7.

17. Jiang, Y.V., Capistrano, C.G., \& Palm, B.E. (2014): Spatial working memory in children with high-functioning autism: Intact configural processing but impaired capacity. Journal of Abnormal Psychology, 123(1), 248.https://psycnet.apa.org/ doi/ $10.1037 / \mathrm{a} 0035420$.

18. Sachse, M., Schlitt, S., Hainz, D., Ciaramidaro, A., Schirman, S., Walter, H. \& Freitag, C.M. (2013): Executive and visuo- motor function in adolescents and adults with autism spectrum disorder. Journal of Autism and Developmental Disorders; 43(5): 1222- 1235. https:// doi. org/10.1007/s10803-012-1668-8.

19. Landa, R. J., \& Goldberg, M. C. (2005): Language, social, and executive functions in high functioning autism: A continuum of performance. Journal of autism and developmental disorders, 35(5), 557. https:// doi.org /10.1007/s10803-005-0001-1

20. Steele, S.D., Minshew, N.J., Luna, B., \& Sweeney, J.A. (2007): Spatial working memory deficits in autism. Journal of Autism and Developmental Disorders, 37(4): 605- 612.https://doi.org/10.1007/ s10803-006-0202-2.

21. Chen, S.F., Chien, Y.L., Wu, C.T., Shang, C.Y., Wu, Y.Y., \& Gau, S.S. (2016): 
Deficits in executive functions among youths with autism spectrum disorders: an age-stratified analysis. Psychological medicine, 46(8),1625-1638.https://doi.org $/ 10.1017 / \mathrm{S} 0033291715002238$.

22. Ozonoff, S., \& Strayer, D. L. (2001): Further evidence of intact working memory in autism. Journal of autism and developmental disorders, 31(3), 257-263.

23. McInnes, M. D., Moher, D., Thombs, B. D., McGrath, T. A., Bossuyt, P. M., Clifford, T.\& Hunt, H. A. (2018): Preferred reporting items for a systematic review and metaanalysis of diagnostic test accuracy studies: the PRISMA-DTA statement. Jama, 319(4), 388-

396.https://doi:10.1001/jama.2017.19163.

24. Lord, C., Rutter, M., \&LeCouteur, A. (1994): Autism diagnostic interviewrevised: A revised version of a diagnostic interview for caregivers of individuals with possible pervasive developmental disorders. Journal of Autism and Developmental Disorders, 24, 659-685.

25. Lord, C., Rutter, M., Goode, S., Heemsbergen, J., Jordan, H. \&Mawhood, L. (1989): Autism diagnostic observation schedule: A standardized observation of communicative and social behavior. Journal of Autism and Developmental Disorders, 19, 185-212.

26. Lord, C., Risi, S., Lambrecht, L., Cook, E.H., Levanthal, B.L., DiLavore, P.C. (2000): The autism diagnostic observation schedule-generic: A standard measure of social and communication deficits associated with the spectrum of autism. Journal of Autism and Developmental Disorders, 30, 205-223.

27. Owen, A. M., Downes, J. D., Sahakian, B. J., Polkey, C. E., and Robbins, T. W. (1990): Planning and spatial working memory following frontal lobe lesions in man. Neuropsychologia, 28, 1021-1034.

28. Corsi, P.M. (1972): Human memory and the medical temporal region of the brain. Dissertation Abstracts International. 34, 891B.

29. Peterson, J., Welch, V., Losos, M., \&Tugwell, P. J. O. O. H. R. I. (2011): The
Newcastle-Ottawa scale (NOS) for assessing the quality of nonrandomised studies in meta-analyses. Ottawa: Ottawa Hospital Research Institute.

30. Lo, C. K. L., Mertz, D., \& Loeb, M. (2014): Newcastle-Ottawa Scale: comparing reviewers to authors' assessments. BMC medical research methodology, 14(1), 45.

31. Goldberg, M. C., Mostofsky, S. H., Cutting, L. E., Mahone, E. M., Astor, B. C., Denckla, M. B., \&Landa, R. J. (2005): Subtle executive impairment in children with autism and children with ADHD. Journal of autism and developmental disorders, 35(3), 279-293.https://doi.org/ 10.1007/s10803-005-3291-4.

32. Edgin, J. O., \& Pennington, B. F. (2005): Spatial cognition in autism spectrum disorders: Superior, impaired, or just intact? Journal of autism and developmental disorders, 35(6), 729.https://doi.org/ 10.1007/s10803-005-0020-y.

33. Kaufmann, L., Zotter, S., Pixner, S., Starke, M., Haberlandt, E., Steinmayr-Gensluckner, M.\&Marksteiner, J. (2013): Brief report: CANTAB performance and brain structure in pediatric patients with Asperger syndrome. Journal of autism and developmental disorders, 43(6), 14831490.https://doi.org/10.1007/s10803-0121686-6.

34. Czermainski, F. R., Riesgo, R. D. S., Guimarães, L. S. P., Salles, J. F. D., \& Bosa, C. A. (2014): Executive functions in children and adolescents with autism spectrum disorder. Paidéia (RibeirãoPreto), 24(57), 85-94.https://doi.org/10.1590/198243272457201411.

35. Macizo, P., Soriano, M. F., \& Paredes, N. (2016): Phonological and visuospatial working memory in autism spectrum disorders. Journal of autism and developmental disorders, 46(9), 29562967.https://doi.org/10.1007/s10803-0162835-0

36. Wang, Z., Jing, J., Igarashi, K., Fan, L., Yang, S., Li, Y., \& Jin, Y. (2018):Executive function predicts the visuospatial working memory in autism spectrum disorder and attention deficit/hyperactivity disorder. 


\section{Hadeer Sobhy Mohammed, et al.,}

Autism Research, 11(8), 1148-1156. https://doi.org/10.1002/aur. 1967

37. Angelini, A. L., Alves, I. C. B., Custódio, E. M., Duarte, W. F., \& Duarte, J. L. M. (1999). MatrizesProgressivasColoridas de Raven: Escala especial. Manual. São Paulo, SP: CETEPP.

38. Raven, J. C., Raven, J., \& Court, J. H. (1988). MatrizesProgressivasColoridas de Raven. Manual (CETEPP). São Paulo, SP: Casa do Psicólogo.

39. Luna, B., Minshew, N. J., Garver, K. E., Lazar, N. A., Thulborn, K. R., Eddy, W. F., \& Sweeney, J. A. (2002): Neocortical system abnormalities in autism: an fMRI study of spatial working memory. Neurology, 59(6), 834-840.https://doi. org/ 10.1212/WNL.59.6.834

40. Minshew, N. J., Luna, B., \& Sweeney, J. A. (1999): Oculomotor evidence for neocortical systems but not cerebellar dysfunction in autism. Neurology, 52(5), 917-917.https://doi.org/ 10.1212/ WNL. 52.5.917

41. Morris, R. G., Rowe, A., Fox, N., Feigenbaum, J. D., Miotto, E. C., \& Howlin, P. (1999): Spatial working memory in Asperger's syndrome and in patients with focal frontal and temporal lobe lesions. Brain and cognition, 41(1), 9-26. https:// doi.org/10.1006/brcg.1999.1093

42. Minshew, N. J., \& Goldstein, G. (2001): The pattern of intact and impaired memory function in autism. Journal of Child Psychology and Psychiatry, 42, 1095-1101. https://doi. 21963001007867

org/10.1017/S00

43. Marcus, R. N., Owen, R., Manos, G., Mankoski, R., Kamen, L., Mc Quade, R. D. \& Aman, M. G. (2011): Aripiprazole in the treatment of irritability in pediatric patients (aged 6-17 years) with autistic disorder: results from a 52-week, open-label study. Journal of Child and Adolescent Psychopharmacology, 21(3), 229236.https://doi.org/10.1089/cap.2009.0121.

44. Perez-Caballero, L., Torres-Sanchez, S., Bravo, L., Mico, J. A., \& Berrocoso, E. (2014): Fluoxetine: a case history of its discovery and preclinical development. Expert opinion on drug discovery, 9(5), 567-578.https://doi.org/10.1517/17460441. 2014.907790.

45. Aarons, M., and Gittens, T. (1999): The handbook of autism: a guide for parents and professionals. Psychology Press.

46. Mace, F.C. and Critchfield, T.S. (2010): "Translational Research in Behavior Analysis: Historical Traditions and Imperative for the Future". Journal of the Experimental Analysis of Behavior 93 (3): 293-312.https://doi.org/10.1901/jeab. 2010. 93-293.

47. Davis, P. S. (2006): The Son-Rise Program: A Case Study of a Family Living with Autism. Ann Arbor, 1001, 48106-1346. 


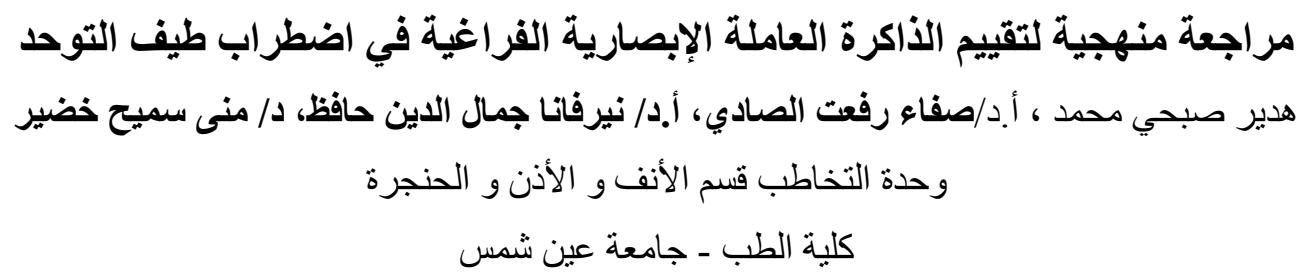

خلفية الدراسة:إن ضعف الذاكرة العاملة والوظيفة التنفيذية هي إحدى النظريات الرئيسية التي تفسر الأسس المعرفية

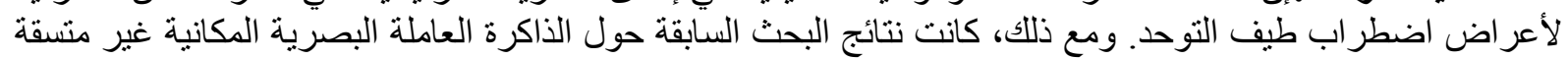
ومتنو عة على نطاق واسع.

الهدف من الدراسة:تهدف هذه الدراسة إلى فحص الأدلة فيما يتعلقبخلل الذاكرة العاملة البصرية المكانية في الأطفال المصابين باضطر اب طيف التوحد. وسوف ينت ذلك من خلال إجر اء مر اجعة منهجية للأدبيات في هذا النطاقالقائم بدر اسلة الأسة ذللك الموضوع.

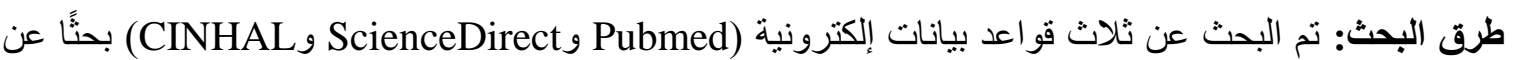
المقالات. وتم تقييم المزيد من الدراسات ذات الصلة وتمت مر اجعة الدر اسات التي حققت معايير الانضمام للار اسة.

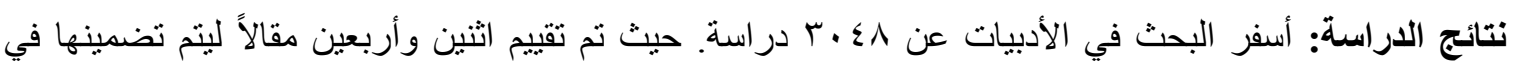

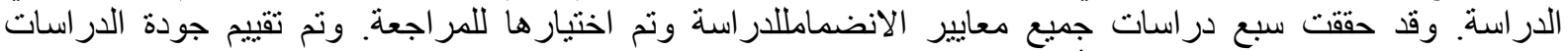

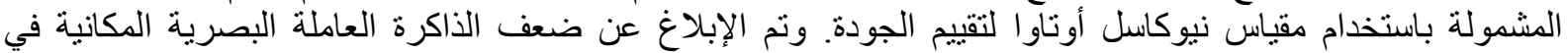

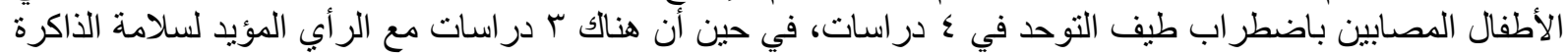

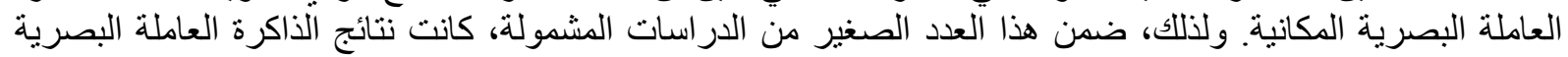
المكانية في اضطر البر طيف التئة ولتوحد مختلفة.

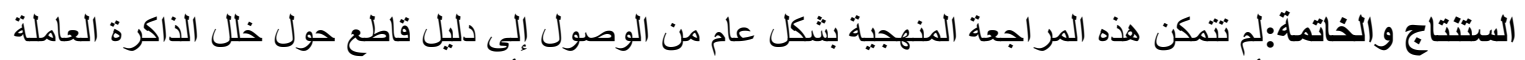

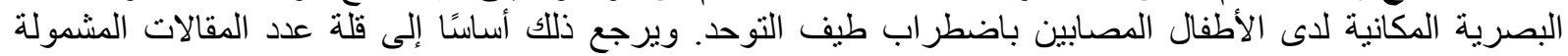

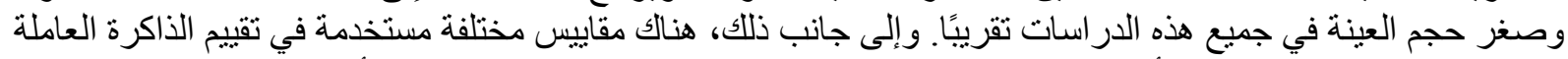

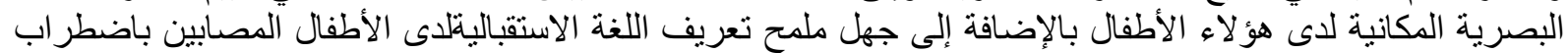

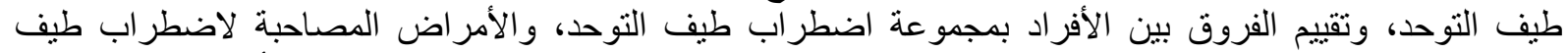

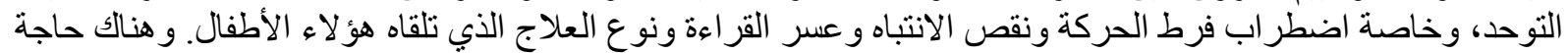

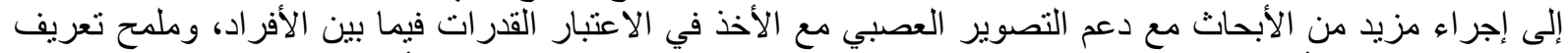

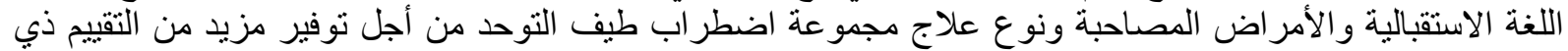

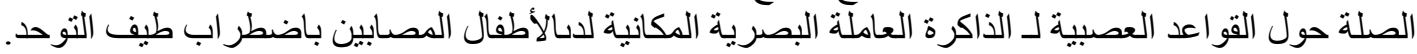

